\title{
タンパク質・アミノ酸栄養と放射線障害について (I) \\ Effect of Protein and Amino acid Nutrition on Radiation Damage in Mice (1)
}

\author{
タンパク質栄養の被曝マウスの生存率に対する影響について \\ Effect of Dietary Protein Nutrition on Survival \\ of Mice exposed to Total-body $\gamma$-irradiation
}

（昭 和 44 年 2 月 6 日受 理）

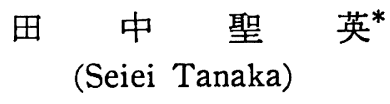

Male dd-weanling mice were fed on $18 \%$ casein diet and on $6 \%$ casein diet for two or three weeks. The survival rates of mice exposed to a single sublethal dose of total body $\gamma$-irradiation $(1,000 \mathrm{R})$ were observed.

The deficiency in protein before irradiation lowered the survival rates of mice. But the decrease in survival rates could be overcome remarkably by the supplement of adequate protein immediately after irradiation. However, addition of excess amount of protein showed an unfavourable influence.

緒論

放射線障害の問題は原子力の平和利用の進展や，いま だ核戦争，核実験による危険から完全に解放されていな い今日に招いて，単に放射線作業従事者のみならず一般 国民としても重要な問題として取り上げなければならな い。

さて生体に対する放射線の影響は直接作用といわれて いる電離粒子が細胞の重要な特定の分子或いは特定の構 造中に電離を生ずるためと，放射線による水の分解によ り生ずる遊離基に起因する問接作用による場合とがあ る。アミノ酸,タンパク質,酵素なとはそれ自身in vitro でも放射線の影響を受けるが，これは $10^{5} 〜 10^{7} \mathrm{R}$ といら 大線量の照射で始めてその影響があらわれる。しかし全 身照射では $10^{3}$ レントゲン以下の線量で既に致死効果が みられる。

生体に対しての放射線の影響は, 造血機能, 生殖器系 統, 消化器系統, それに眼組織などに比較的顕著にあら われる。そこで先ず造血機能, 消化器系統に対する放射 線の影響について泩目してみよう。

先ず血液に対する放射線の作用は，血液を構成してい、 る物質に対する作用と，全身の影響としてあらわれる血 液の変化に分けて考えられる。前者の構成分 (タンパク

\footnotetext{
* 都立アイソトープ研
}

質, 酔索など）に対する影響は前述の上うに $10^{4} \sim 10^{7}$ 程 度の大線量で始めてあらわれるが，後者の影響は血液像 特に白血球数の変化は数レントゲン程度の少線量でもそ の変化を検出しらるといわれている。

このような放射線による变化は如何にして起るかにつ いて述べてみよう。血液には水分が多くそのため水に起 る照射変化すなわち電離拉よび励起の結果, イオンや遊 離基を生じ，これらが 2 次的に血液内の物質に作用する わけである。この場合酸素存在下ではこれらの遊離基の 産生が增加する。血液中の水以外の構成分としてはタン パク質, アミノ酸, 酵素, 塩類などがあり,これらに対 寸る放射線の影響としては大線量照射の場合, 脱了ミノ 反応やペプチド結合の切断, 紫外線吸収スペクトルの変 化, 酸化, 凝集沈澱反応, 粘度变化などがあらわれる。 酵素については SH 酵素が放射線感受性が高いとされて おり, 放射線エネルギーの吸収により水に生じた $\mathrm{OH}$, $\mathrm{H}_{2} \mathrm{O}_{2}, \mathrm{HO}_{2}$ などの遊離基と $\mathrm{SH}$ 酵素が反応して不活性 化すると考えられている。このことはグルタチオンなど の還元剛の添加により再活性化が起ることから実証され ている。

ここで問題としたいのは生体全体に対する放射線の影 響として血液に見られる変化で，造血機能の障害を問題 にしなければならない。 
循環血液細胞は比較的放射線に対して抵抗性があり， 全身照射により末梢血液にみられる变化は造血臟器の障 害に起因するすので, その細胞の寿命の短いものほど早 期にかつ著るしい変化があらわれる。赤血球の変化は遅 く, 白血球, 血小板の変化が早い。1 回全身照射の場合 25〜100レントゲン以上の線量では 造血臟器の 完全な回 復はみられないといわれている。分割照射の場合は 1 回 照射の場合に比べて全照射線量は大であってもその影響 は少ない。しかし影響は少ないとはい蓄積線量として 線量の絶対値が增せばそれに応して影響が出てくる。す なわち職業性被曝の場合は造血缄器の若い芽細胞の減少 をきたし,その結果として高色索性貧血, 白血球减少症, リンパ球相対的增加症などが括こる。

赤血球については $\mathrm{LD}_{30}$ 程度の線量を照射したときは 1 週間後より赤血球数は減少し, 数週間後に最低値に達 する。赤血球は大小不同，变形，多染性などをきたし，甚 だしい障害の場合には浱染大形および有核赤血球があら われる。一般的に放射線による赤血球系統の慢性変化は 貧血である。1 回の大線量照射，或いは長期間照射に上 り再生不良性盆血打上び高色案性蚠血がみられる。溶血 現象す古くから知られている。電子影徽鏡像からは形態 学的に酸処理による変性と類似した膜の変化であるとい われている。血液凝固, 化学的成分, 酸塩基平衡にも変 化をきたすか，照射の方法，照射線量，動物の種類，測 定時期などにより著しく異なっている。

血液中の酵素についてもいろいろ実験が行なわれ， GOT, LDH, カタラーゼ, コリンエステラーゼ, 血清 アルカリフォスファターゼ, アリエステラーゼなどが変 化すると報告されている1)。

造血機能をみる方法としては放射性鉄の造血臓器への 取り込みを指標とする方法か用いられている。これにつ いては第 2 ，第 3 報にゆずる。

さて次は消化器系統に対する障害であるが，消化管は 古くからその感受性の大きいことが認められ，悪心，嘔 吐, 下痢, 食欲不振, 体重減少などの現象か放射線の影 響によるものとされていた。近年動物実験から放射線障 害死の 1 つの型としてこの系の障害による死亡すなわち 消化管死として取り上げられた ${ }^{23)}$ 。消化管死は殆んど 凡ての実験動物にみられ，1,000 レントゲン程度の照射 で照射後 $3 ， 4$ 日に起る。この死亡は腹部を鉛で覆らこ とにより防ぐことができる。また消化管系統の部分照射 でも同様の致死効果が認められている゙。

消化管系統の障害によって起ると思われる症状の中で 食欲の低下は被嚗動物に一般的に認められる現象で胃の 内容物移動時間の遅れや"，消化管の内容推進運動の低 下の)によるとされている。悪心および湢吐については,
はっきりしたことは不明であるが，消化管内の毒物にし たことは不明であるが，消化管内の毒物による刺激から くる知覚神経の反射中嘔吐中权の興隹, さらに胃液分泌 の增加7)，酸度の変化8) などによりこのような現象が起 るとされている。

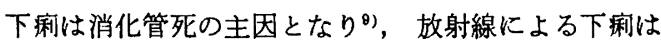
通常の下㥒と異なり，その原因が食物ではなく消化管そ のものにあることである。すなわち消化管の運動六進 ${ }^{6)}$, 食物, 水分の消化吸収の不全によるためである。この場

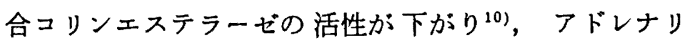
ン，七ロトニン，ヒスタミンなどの照射前投与で保護効 果が認められているがその作用機構については不明の点 が多い。

照射によって動物は体重および消化管重量の減少がお こるが，この場合強制給餉をやってもこの現象を防ぐこ とは出来ず，これは単に食欲の低下によるすのだけでは ない11)。また照射によって血糖値が上界するが212)，これ は腸管のブドウ糖の透過性の低下と他の臓器の糖利用の 低下の両方によっておこると考えられる。また消化管重 量の变化については粘膜の損傷が重要な役割を果たして いるという考光方もある ${ }^{13)}$ 。放射線障害の場合には水分 および電解質代謝の変化が認められるが，消化管系統で は被㩧に伴 5 高度の下痢によって水分扣よび電解質 $(\mathrm{Na}, \mathrm{K})$ が急速に失われ，それが急性死の原因の $1 つ$ になるのである14)。特にNaについてはこの影響が著し l.o

次に外からの栄養の放射線障害に対する影響について 先人の業䥊を振返ってみょう。先ずカロリーについてみ ると，低カロリ一食で飼育したラットは自由に飼料を与 えて飼育したものに比べて放射線の影響を受け易く, $\mathrm{LD}_{50}$ が低くなるとい5 Carroll らの実験がある ${ }^{15)}$ 。体 重は栄養状態の総合をあらわしているわけであるが，こ れに関しては体重の大きい動物の方が体重の小さいもの に比べて照射による死亡率が低いという Quastler ${ }^{18)}$, Hagen $^{17)}$ ，Niaman ${ }^{18)}$ らの報告があるがまた全然体重と は無関係であるとい5 $\mathrm{Abrams} \mathrm{s}^{10}$ の報告もある。

タンパク質, アミノ酸栄養に関しては Jennings ${ }^{20)} の$ 報告がある。彼は低タンパク質餇料で餉育したラットを 照射した場合，その死亡率をみると標集タンパク質飼料 で飼育したラットに比べて高く、これはラットが低タン パク質飼料にて飼育されることにより造血機能が低下寸

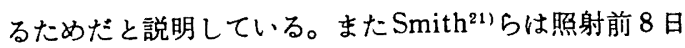
間または 3 週間標準タンパク質飼料 $(18 \%)$ または低タ ンパク質飼料（6\%）で飼有した動物を照射後低タンパ ク質飼料または高タンパク質飼料 $(60 \%)$ にて飼育して 死亡率，白血球，赤血球，酸素吸収率などをみている。 


\section{栄 養}

彼らは低タンパク飼育ラットは照射により死亡率が高 く，照射後飼料のタンパク質含有量を標準タンパク飼料 のタンパク量に㞍しても死亡率に変化をきたさず，照射 後超高タンパク質飼育にすると死亡率の低下がいくらか 起ると報告している。またメチオニン，シスチンすなわ ち含硫了ミノ酸についてもその照射後の添加効果は認め られず, 白血球, 赤血球の增减にはタンパク質食餌の影 鄉は殆んど認められない。

また網状赤血球についてはタンパク質添加によりいく らか照射に上り減少する現象が回復する。また血球の酸 索吸収す低タンパク質飼育では標準タンパク質飼育に比 べて低く，超高タンパク質飼育では高いという結果を得 ている。Duplan ${ }^{22)}$ はモルモットによる実驗で飼料のタ ンパク質を標準タンパク質含有量より少なく增加させる ことによりX線の広範囲にわたる線量の全身照射に対す る抵抗性が增加すると報告している。その他タンパク質 栄養と放射線障害についての仕事として, タンパク質源 として肝臓を加えて, 血清タンパク質量の変動をみた Oganezova ${ }^{23}$ )の仕事や, 白血球, 体重などの変動をみた

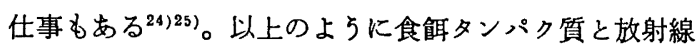
に関しては，低タンパク食䬺が放射線感受性を高めるこ とはほほ明らかであるが, 高タンパク食飰やフミノ酸配 合食餌などの影響については不明の点が多い。

他の栄養素すなわち脂肪酸やビタミンについてはDecker ${ }^{28)}$ らはマウスについて不可欠脂肪酸が 欠乏すると 照射後の死亡率が增すと報告して拈り，また Cheng ${ }^{27)}$ らはラットについて分割照射および 1 回照射に対する脂 肪酸の過剩投与を行ない, 分割照射では脂肪酸の投与効 果がみられたが，1回照射ではその効果がみられなかっ

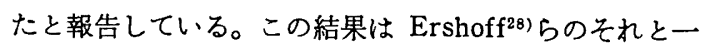
致している。ビタミンについては $\mathrm{B}_{1}{ }^{29)}, \mathrm{C}^{30)}, \mathrm{B}_{12}{ }^{31)}$, $\mathrm{K}^{32)}$ が全身照射て滅器内での变化が著しいことが報告さ れている。

以上栄養全般と放射線障害について概要を述べてきた が第一報として食餌タンパク質に注目して生体の総合現 象である死亡率を指標として放射線障害に対するタンパ ク質栄養の影響について報告する。なおこの実験の 1 部 は予報として揭載しているる34。

\section{実験}

実験動物：ddN の雄 4 週令（体重 $10 \mathrm{~g} \pm 1 \mathrm{~g}$ ）のもの を用いた。

飼料：固型飼料はオリエンタル固型飼料をまた配合飼 料は表 1 に示寸組成のものを用いた。

飼有：マウスを金網䌘のケージに 1 室当たり 2 匹の割 合で入れ，オリエンタル固型飼料にて 1 乃至 2 週間なら

\begin{tabular}{cc|lc}
\multicolumn{4}{|c}{ 表 1} \\
\hline 成 分 & $(\%)$ & * 成 分 & $(\%)$ \\
\hline ミルクカゼイン & $18^{* *}$ & $\mathrm{NaCl}$ & 4.04 \\
イースト末 & 2 & $\mathrm{~K}_{2} \mathrm{HPO}_{4}$ & 22.3 \\
肝油大豆油(1:3) & 6 & $\mathrm{CaHPO}_{4} \cdot 2 \mathrm{H}_{2} \mathrm{O}$ & 22.3 \\
マッカラム塩* & 4 & $\mathrm{Ca}-\mathrm{lactate}^{*}$ & 5.74 \\
パンビタン末 & 1 & $\mathrm{Fe}-\mathrm{citrate}$ & 2.74 \\
$\alpha$-澱 粉 & 69 & $\mathrm{MgSO}_{4} \cdot 7 \mathrm{H}_{2} \mathrm{O}$ & 12.7 \\
& & $\mathrm{NaHPO}_{4} \cdot 12 \mathrm{H}_{2} \mathrm{O}$ & 10.52 \\
\hline
\end{tabular}

**標準タンパク質含有量とする。

し飼いを行ない,その後実験に応じてそれぞれの配合飼 料にて飼育を行なった。水と慨は自由に与え, 毎日新し いものと取り換えた。飼料の量はマウスの成長に伴51 日の摄取栄養に不足を来たさぬ上うに充分量与えた。す なわち交換時には常に若干の食べ残しがあるようにし た。また各実験群の選別は無差別に行ない，各群は10匹 以上のマウスを用いた。

$r$ 線照射：マウスを照射用のケージ（マウス1匹がや っと動ける程度の大きさに室分けしたもの）に入れて照 射を行なった。 $\gamma$ 線源はコン゙ルト $60,1,000$ キューリー および 3,000 キューリーで高さ床面より $0.7 \mathrm{~m}$ 水平距離 3 乃至 $4 \mathrm{~m}$ にて行なった。

\section{結果および考察}

\section{1) 照射線量の決定}

本実験に使用する ddNマウスに対する Co-60 r 線の $\mathrm{LD}_{50} / 2$ 乃至 3 週に相当する 線量を知るために次の実験 を行なった。すなわちマウスを前述のよ5に固型飼料に て2 週間飼育し，10匹を 1 群として表 2 に示す条件にて $\gamma$ 線全身 1 回照射を行ない，照射後引きつつき同飼料に て飼育し, マウスの生存数を毎日観察した。結果は表 3 に示した。表 3 の結果から 2 乃至 3 週間とい5比較的短

表 2

\begin{tabular}{|c|c|c|c|c|}
\hline 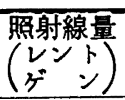 & 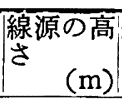 & $\begin{array}{r}\text { 線源からの } \\
\text { 水平距離 } \\
(\mathrm{m})\end{array}$ & $\mid \begin{array}{l}\text { 線量率 } \\
/ \mathrm{hr}\end{array}$ & $\begin{array}{c}\text { 照射時間 } \\
\text { (帱·分) }\end{array}$ \\
\hline 600 & 0.7 & 3 & 108 & 5.53 \\
\hline 800 & 0.7 & 3 & 108 & 7.37 \\
\hline 1,000 & 0.7 & 4 & 65.5 & 15.33 \\
\hline 1,200 & 0.7 & 4 & 65.5 & 18. 35 \\
\hline
\end{tabular}


表 3

\begin{tabular}{|c|c|c|c|c|c|c|c|c|c|c|c|c|c|c|c|c|c|c|}
\hline \multirow{3}{*}{ 照射線量 } & \multicolumn{18}{|c|}{ ddN マウスの照射後の生存数 } \\
\hline & & & & & & & & 射後 & の日娄 & & & & & & & & & \\
\hline & 1 & 2 & 3 & 4 & 5 & 6 & 7 & 8 & 9 & 10 & 11 & 12 & 13 & 14 & 15 & 16 & 17 & 18 \\
\hline 600 & 10 & 10 & 10 & 10 & 10 & 10 & 10 & 10 & 10 & 10 & 10 & 10 & 10 & 10 & 9 & 9 & 9 & 9 \\
\hline 800 & 10 & 10 & 10 & 10 & 9 & 9 & 9 & 9 & 9 & 8 & 7 & 6 & 6 & 6 & 6 & 6 & 6 & 6 \\
\hline 1,000 & 10 & 10 & 10 & 9 & 9 & 9 & 9 & 8 & 7 & 7 & 6 & 6 & 6 & 6 & 4 & 4 & 4 & 4 \\
\hline 1,000 & 10 & 10 & 10 & 10 & 9 & 8 & 8 & 6 & 5 & 4 & 4 & 4 & 4 & 3 & 3 & 3 & 3 & 3 \\
\hline
\end{tabular}

表 4

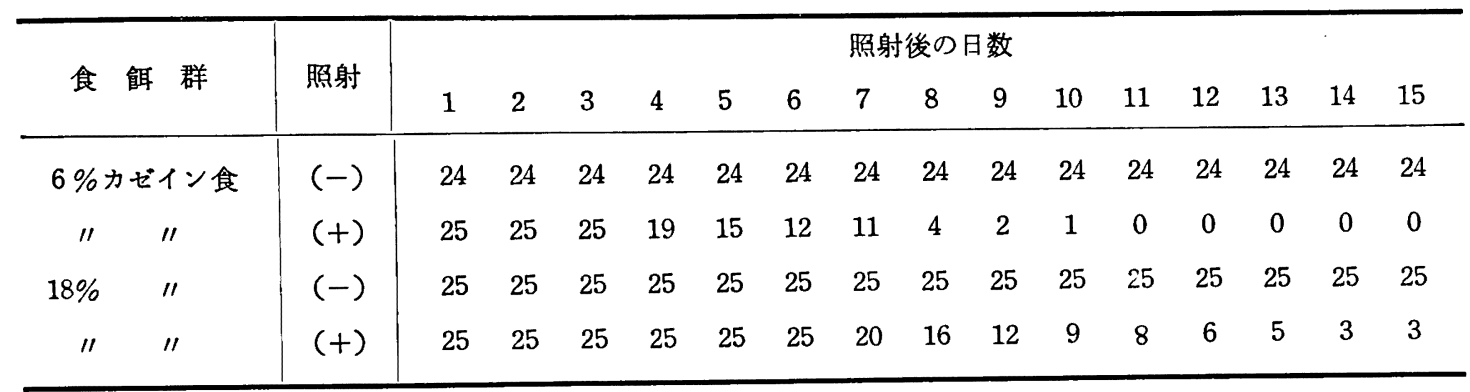

期間に約半数が死亡するような照射線量としては 1,000 レントゲン程度が適当であろうと思われる。従って死亡 率をみる実験に関しては 1,000 レントゲンを用いること にした。

\section{2) 低タンパク飼育マウスに対する照射の影響}

マウスを低タンパク食餉 (カゼイン $6 \% *)$, 標準タン パク食餌（カゼイン18\%）にてそれぞれ3週間飼育し， コバルトによる照射 $(1,000$ レントゲン, $178 \mathrm{R} / \mathrm{hr})$ を 行ない, 照射後も引きつつき同飼料にて飼有し照射後の 生存数を観察した。結果を表 4 亿示す。

表 4 の結果から，低タンパク質飼育のマウスは明らか に標準タンパク質飼育のそれに比べて死亡率が大であっ た。また照射の影響は照射後 3 乃至 4 日頃から急激に表 われてきた。これは消化器系統の障害と食欲低下による 体力消耗とが重なってあらわれたためと理解できる。こ の結果は Smith ${ }^{22)} ら お よ ひ ゙ ~ J e n n i n g s^{21)} ら の$ 結果と一致 している。

3）照射後のタンパク質栄養の死亡率に及ぽす影瑤につ いて (1)

次に照射後のタンパク質栄㙓が如何に死亡率に影響を 及はすかについて実験を行なった。すなわちマウスを前 実験と同㥞館ならしを行なった後, 低タンパク質食慨に て3 週間飼育し, 照射後標瑯タンパク質食慨に戻してそ

* 12\%相当のタンパク質の不足はカロリーとして糖質 ( $\alpha$-デン粉)で補った。
の照射後のタンパク質補足による放射線障害の回復効果 をみた。照射条件は前実験と大体等しい。照射後の経時 な生存数を表 5 に示す。

表 5 の結果から照射群についてみると6-18群は 6 6 群に比べて明らかに高い生存数を示し，18一-18群にほ は近い様相を示した。このことは低タンパク質食䬦飼有 マウスに照射後タンパク質を標準タンパク質量迄補足す ると死亡率の低下すなわち回復効果がみられた。すなわ ちタンパク質量の死亡率に対する効果は照射前より照射 後の方が大きいことがみられた。この結果は Smith ${ }^{22)}$ らの照射後のタンパク質栄養は生存率に有意の差を生ぜ しめなかったといら報告と相反する。

4) 照射後のタンパク質栄養の死亡率に及注す影響につ いて (2)

3) にて低タンパク質飼育マウスに付き照射後タンパ ク質を標準タンパク質量にまで補足することにより明ら かな延命現象がみられたので，さらに照射後のタンパク 質添加量につき量的な検討と照射前に与えると防護效果 があるとされている含硫つミノ酸のメチオニンにつき, その添加実験を行なった。また前実験とは逆に照射前標 準タンパク質食慨にて飼育したマウスを照射後低タンパ ク質食餉に切換えた実験も行なった。結果を表 6 に示す。

表 6 の結果より過剩のタンパク質補足はむしろ死亡 率を高める効果を示した。また照射後標軯タンパク質 飼育を低タンパク質飼育に切り換えた群については照射 
表 5

\begin{tabular}{|c|c|c|c|c|c|c|c|c|c|c|c|c|c|c|c|c|c|c|c|}
\hline & 食 & 耳 & 群 & 照 & & & & & & & & 射後 & の日数 & & & & & & \\
\hline & 照射前 & & 照射後 & 射 & 1 & 2 & 34 & 45 & 56 & 7 & 8 & 10 & 1112 & 13 & 1715 & 516 & 1718 & 819 & $\begin{array}{l}920 \\
21\end{array}$ \\
\hline $6 \%$ & カゼイン食 & $6 \%$ & カゼイン食 & - & 11 & 11 & 111 & 111 & 1110 & 10 & 101 & 10 & 1010 & 10 & 101 & $\begin{array}{ll}0 & 10\end{array}$ & 1010 & & o \\
\hline & " & & $\prime \prime$ & + & 20 & 20 & 202 & 202 & 2018 & 18 & 181 & 816 & 1513 & 10 & 86 & 6 & 66 & 65 & 4 \\
\hline & $\prime \prime$ & $18 \%$ & カゼイン食 & - & 12 & 12 & 121 & 121 & 1212 & 12 & 121 & 212 & 1111 & 11 & 1111 & 111 & 1111 & 111 & 1111 \\
\hline & $\prime \prime$ & & $\prime \prime$ & + & 20 & 20 & 202 & 202 & 2019 & 19 & 171 & 14 & $14 \quad 14$ & 12 & 1211 & 111 & 1111 & 111 & 111 \\
\hline $18 \%$ & カゼイン食 & & $\prime \prime$ & - & 18 & 18 & 181 & 181 & 1818 & 18 & 181 & 18 & 1818 & 18 & 1818 & 818 & 1818 & & 18 \\
\hline & " & & " & + & 20 & 20 & 202 & 202 & 2020 & 19 & 191 & 18 & $17 \quad 15$ & 14 & 1211 & 11 & 1111 & & 1111 \\
\hline & & & 表 6 & . & & タン， & パク & 質補 & 甫足の & 死亡 & 率に历 & 伊す景 & 影響（2 & & & & & & \\
\hline & 食 & 耳 & 群 & 照 & & & & & & & & 射後 & 刀日数 & & & & & & \\
\hline & 照射前 & & 照射後 & 射 & 1 & 2 & & 3 & 4 & 5 & 6 & 7 & 8 & 9 & 10 & 11 & 12 & 13 & 14 \\
\hline $6 \%$ & カゼイン食 & $6 \%$ & カゼイン食 & - & 9 & 9 & & 9 & 9 & 9 & 9 & 9 & 9 & 9 & 9 & 9 & 9 & 9 & 9 \\
\hline & "I & & "I & + & 19 & 19 & & 19 & 17 & 15 & 15 & 15 & 11 & 11 & 7 & 4 & 4 & 2 & 2 \\
\hline & "I & $18 \%$ & "I & + & 20 & 20 & & 20 & 20 & 19 & 19 & 18 & 17 & 16 & 15 & 14 & 14 & 12 & 11 \\
\hline & $\prime \prime$ & $30 \%$ & " & + & 20 & 20 & & 20 & 18 & 17 & 15 & 15 & 13 & 11 & 10 & 7 & 6 & 6 & 4 \\
\hline $18 \%$ & "1 & $6 \%$ & " & + & 20 & 20 & & 20 & 20 & 19 & 19 & 19 & 12 & 8 & 5 & 3 & 3 & 3 & 3 \\
\hline & "I & $18 \%$ & " & + & 19 & 19 & & 19 & 19 & 19 & 18 & 17 & 16 & 16 & 15 & 14 & 13 & 11 & 10 \\
\hline $6 \%$ & " & $6 \mathrm{~A}^{*}$ & & + & 20 & 20 & & 20 & 20 & 19 & 15 & 14 & 12 & 12 & 9 & 7 & 7 & 5 & 4 \\
\hline
\end{tabular}

6A*6\%カゼイン食慨に0.3\%のメチオニンを添加した。

による障害が強くあらわれ，照射前後と低タンパク質飼 育した群に，ほほ等しい㥞相を呈した。メチオニン添加 群に関しては文献では照射により SH 酵素が阻害される という報告 ${ }^{35)}$ や へモグロビンの中の放射線感受性の高 いアミノ酸として知られているが ${ }^{36)}$, 食慨として与えた 本実験ではその添加効果は認められなかった。前述のこ の過剩タンパク質の悪効果は前述の ${ }^{12) 22}$ の Smith の60 \%カゼイン食による実験と一致している。

5) 照射後のタンパク質栄養の死亡率に及ほす影響に つい (3)

4）の実験でタンパク質の過剩投与により死亡率に関 して負の効果がみられたのでその原因追及と再確認の目 的で次の実験を行なった。すなわちマウスを低タンパク 質食慨にて飼育し, 型通り照射を行なったのち, 食慨を 30\%カゼイン群，54\%カゼイン群に切り換えたものと， $6 \%$ カゼイン食慨を 1 週間毎に順次 $54 \%$ ガ゙イン食餌迄 カゼインの含有量を增加した食䬲に切り換えたもにつ き，照射後の生存数を観察した。

さてこのタンパク質過剩投与による負の効果は次のよ
5に考えられる。すなわち $6 \%$ カゼイン食で飼育したマ ウスは食䬦によるタンパク質の不足で体重の減少をきた し，照射によりさらに消化管系統の障害が起る。そのた めに多量のタンパク質をあとから与えてすマウス自身が それを吸収する能力が低くかえって消化不良による障害 が強くあらわれると思われる。緒論でも述べたよ5に照 射されると食欲が低下し, 摄取食䬦量が減少するが死亡 率に関しては強制給餌して食慨量を元に戻しても照射に よる死亡率の上年を下げることはできなかったといら報 告 ${ }^{37)}$ からす理解できる。糖質の実験で Ershoff ${ }^{29)} ら は$ 照 射後の糖質源としてブドウ糖の方が蔗糖やデキストリン などの多糖類に比べて生存率を高めるのに適していると いう仕事からす消化管系統の障害が問題となっているこ とは十分理解できる。この意味から前述のごとく消化管 系統に負担をできるだけ少なくする目的でタンパク質含 有量を徐々に增加させた食餌群による実験を試みたので ある。結果を表 7 に示す。

表 7 の結果より前実験で得られたと同様に，照射後タ ンパク質を過剩に添加した群は標準タンパク質量飼育に 


\begin{tabular}{|c|c|c|c|c|c|c|c|c|c|c|c|c|c|c|c|c|c|c|c|c|c|c|c|c|}
\hline 食 & \multirow{2}{*}{\multicolumn{2}{|c|}{$\begin{array}{c}\text { 群 } \\
\text { 照射後 }\end{array}$}} & 照 & \multicolumn{21}{|c|}{ 照射後の日数 } \\
\hline 照射前 & & & 射 & 1 & 2 & 3 & 4 & 5 & 6 & 7 & 8 & 9 & 10 & 11 & 12 & 13 & 14 & 15 & 16 & 17 & 18 & 19 & 202 & 21 \\
\hline 6\%カゼイン食 & $18 \%$ & ゼイン食 & + & 30 & 30 & 30 & 28 & 26 & 24 & 22 & 21 & 21 & 21 & 20 & 19 & 18 & 17 & 17 & 17 & 17 & 17 & 17 & 171 & 17 \\
\hline$\prime \prime$ & $30 \%$ & $\prime \prime$ & + & 30 & 30 & 30 & 27 & 25 & 22 & 21 & 20 & 20 & 19 & 17 & 15 & 14 & 13 & 13 & 13 & 12 & 12 & 12 & 121 & 12 \\
\hline$\prime \prime$ & $54 \%$ & " & + & 28 & 28 & 26 & 24 & 20 & 17 & 14 & 13 & 12 & 12 & 10 & 10 & 9 & 8 & 8 & 6 & 6 & 6 & 6 & $6 \epsilon$ & 6 \\
\hline$\prime \prime$ & G* & & + & 27 & 27 & 25 & 22 & 19 & 17 & 17 & 16 & 16 & 14 & 13 & 12 & 11 & 11 & 11 & 11 & 11 & 9 & 9 & $9 \leqq$ & 9 \\
\hline
\end{tabular}

注 G* Gradnal Supplement の意味で1週ごとに 18\%，24\%，30\%，54\%とカゼイン含有量を增加した食餌群で ある。

民した群に比べて高い死亡率を示した。また徐々にタン パク質含有量を增加していった群は予想に反して標準タ ンパク質で照射前後を通した群より高い死亡率を示し た。しかし照射直後過剩タンパク投与群よりは幾分低い 値を示した。この結果は增加順序がカゼイン $18 \%$ から 24 $\%, 30 \%, 54 \%$ と急激に增加したので，消化管系統の回 復がこれに追い付かなかったためではないかと思われ る。故に増加の順序をるっと低いカゼイン含有量から始 めればその段階的タンパク質の添加効果がみられたので はないかと考えられる。

\section{結論}

1) 照射前後のタンパク質栄養はともに照射後の生存 率に影㸷を及はし，低タンパク質食慨飼育は高タンパク 質食慨飼育より放射線に対する感受性が高いことを示し た。

2）照射後低タンパク質食慨飼育を標準タンパク質食 慨飼育に切り換えると死亡率の回復がみられた。

3) 照射後のタンパク質の過剩添加はむしろ死亡率を 高めた。

据筆に当たりご留篤なるご指導，ご校閲を賜わった東 大吉川春寿教授を始めとして金大米山良昌教授, 九大水 上茂樹教授に深甚なる感謝の意を表わすとともに本研究 に際し種々便宜を計られた味の素K.K. , 田辺アミノ酸 研究基金に潹謝する。

\section{文献}

1) Deutsch, L.: Strahlen Therapie, 48, 114(1933)

2) Nickson, J. J., Bane, H. N., "Physiological Effect of Radiation, Radiation Hygien Handbook" Mc Graw-Hill (1959)

3) Quastler, H.: Rad. Res., 4, 303 (1956)

4) Swift, M. N., Taketa, S. T.: Am. J. Physiol., 185,85 (1956)

5) Goodman, R. D. Lewis, A. E. Schuck, E. A.: Am. J. Physiol., 169, 242 (1952)

6) Conard, R. A.: Am. J. Physiol., 165, 375 (1952)
7) Nersterin, N. F.: Med. Radiol., 3, 61 (1958)

8) Fox. B. F., Littman, A.: Castrooenterogy, 24, 517 (1953)

9) Jakson, K. L., Rhodes, R., Entenman, C. : Rad. Res., 8, 361 (1958)

10) Burn, J. H., Kordik, P., Male, R. H.: Brit. J. Pharmacol., 7, 58 (1952)

11) Smith, W. W., Ackermann I. B., Smith, S.F.: Am. J. Physiol., 168, 382 (1952)

12) Kay, R. E., Entenman, C.: Proc. Soc. Exptl. Biol. Med., 91, 143 (1956)

13) Kay, R. E., Entenman, C.: Am. J. Physiol., 197, 13 (1959)

14) Caster, W. O., Armstrong, W. D.: Rad. Res., 5, 189 (1956)

15) Carroll, H. W. Brauer, R. W.: Rad. Res., 11, 435 (1959)

16) Quastler, H.: Am. J. Roent., 54, 457 (1949)

17) Hagen, C., Sacher, G.: MDDC-1252-CH-3754 (1946)

18) Niaman, D. N.: Am. J. Roent. 61, 95 (1949)

19) Abrams, H. L.: Proc. Soc. Exp. Biol. Med., 76, 729 (1951)

20) Jennings, F. L.: Proc. Soc. Exp. Biol. Med., 72, 487 (1949)

21) Smith, W. W., Ackermann, I. B., Alderman, I. M.: Am. J. Physiol. 169, 491 (1952)

22) Duplan, J. F.: Comp. Rend. Acad. Soc. 236, 424 (1953)

23) Oganezova, A. A.: Vop. Pitan., 18, 2, 49 (1959)

24）藤井正道：日医放誌， 17，349（1957）

25) Oganezova, A. A.: Vop. Pitan., 17, 3, 38 (1958)

26) Decker, A. B., Mead, J. F.: U. S. Atomic Energy Commission Document UCLA-52 (1949)

27) Cheng, A. L.S., Kryder, G. D., Bergquist, L., Deuel, H. J. Jr. : J. Nutr., 48, 161(1952)

28) Ershoff, B. H. : J. Nutr., 47, 289 (1952)

29）橋本啓明：日医放誌，19，1119 (1959)

30）橋本啓明：日医放誌，19，1132（1959）

31）平川和也：日医放誌，19，832（1959）

32) Ellinger, F. : Rad. Res., 6, 355 (1957)

33) Abe, K.S. Kumta, U.S., Tappel. A. L. : Rad. Res., 15, 709 (1961)

34) Tanaka, S., Nukazawa, A., Yoshikawa, H., Yoneyama, Y. : Nature 197, 305 (1963) 